JES FABRICIUS M ØLLER

\section{Venskab og strid}

K.E. Logstrup \& Hal Koch: Venskab og strid, indledning ved Henrik S. Nissen, efterskrift ved Ove Korsgaard, Klim, 2010, 263 sider, 299,- kr.

I 1992 udgav nu afdøde Henrik Nissen de dele af brevvekslingen mellem K.E. Løgstrup og Hal Koch, som stammer fra besættelsestiden, en udgivelse, der har vundet status som nyklassiker. Brevene er et reservoir af erfaringer og formuleringer, som nu indgår i den erindringspolitiske kamps standardrepertoire, når det handler om besættelsestiden.

I denne nye udgave af brevvekslingen, der indgår i Forlaget Klims fortjenstfulde serie af Løgstrupudgivelser, er der medtaget breve fra både før og efter krigen, der - som det hedder i udgivernes forbemærkning - "skønnes at have offentlighedens interesse". Det indebærer med andre ord, at nogle af de bevarede breve ikke trykkes. Denne udeladelse må der være en rigtig god grund til, som imidlertid forholdes læseren. De tre korte breve fra efterkrigstiden, alle fra Koch til Løgstrup, er kun af be- grænset interesse, dog med det forbehold, at det fra 1950 rummer invitationen til Løgstrup til at komme og tale på Krogerup over temaet humanisme. Det var det foredrag, der lagde grunden til Den etiske Fordring, som Hal Koch i øvrigt læste med "intens nydelse", som han skrev i 1956.

De ti breve fra perioden 193436 er en anderledes udfoldet intellektuel meningsudveksling. Især Løgstrup lagde hele sit akademiske hjerte i brevene, mens Koch også fik stunder til at meddele sig om hverdagens tildragelser og på sin egen kirkehistoriske facon mindet sin ven om, at han også skyldte at fortælle noget om familien og livet i Tyskland: "dine Breve minder om den ortodokse Tids Prækener: man kan paa dem ikke se i hvilket Aarhundrede eller hvilket Land, for hvilke Tilhørere eller af hvilken Præst, de er holdt. [...] Af Overskriften fremgaar det, at du bor i Tübingen, af Underskriften, at der vedblivende eksisterer en Person, der hedder Rosemarie - og dermed Basta." (7/8-35)

Løgstrups brev til Koch 19/635 er en lang refleksion - foranlediget af et spørgsmål stillet af $\mathrm{Hal}$ Koch - over begrebet historie med 
afsæt i nogle noter, som han i sin tid havde taget til nogle forelæsninger og øvelser hos Hans Lipps. Det er et filosofihistorisk dokument, der antagelig ville vække interesse, hvis det blev oversat til tysk. Hal Kochs svar (7/8-35) er ikke mindre interessant, fordi han her udfoldede sit begreb om kirkehistorie. Han stod som kirkehistoriker i den liberalteologiske tradition, der anvendte historievidenskabens kildekritiske principper, men samtidig opfattede Hal Koch sig teologisk som kritiker af den liberale teologi, og kirkehistorien stod for ham i teologiens tjeneste. "Teologi bestemmer jeg paa Barthsk vis som Kritik af den kirkelige Forkyndelse. Den udspringer af den Nødsituation, at Evangeliet skal forkyndes, hvilket kræver, at man i al Beskedenhed gør sit yderste for at forkynde det ret". En anstrengelse, der ifølge Hal Koch alt for ofte var forgæves, fordi mennesket kun har begrænsede evner over for Gud. Kirkehistorien skulle heller ikke lægge sig efter at "konstatere det guddommelige i Historie eller opfatte særlige religiøse Fænomener; en saadan Metode vil føre til Gnosis og Teosofi”. En kirkehistoriker skulle arbejde præcis så metodisk og rationelt som en profanhistoriker, men med en anden intention, en anden opgave for øje, nemlig at der skal prædikes på søndag. I brevene ud- folder Hal Koch også sin barthianske kritik af Oxfordbevægelsen.

Brevvekslingen 1940-43 var præget af alvoren $\mathrm{i}$ den politiske situation. Akademiske spørgsmål trængtes i baggrunden. Striden mellem vennerne gik ikke så meget på målet for det politiske arbejde som midlerne. Det handlede for dem begge om at sikre et frit og demokratisk Danmark, men mens Løgstrup hurtigt ønskede at gå langt for at fremkalde et brud med tyskerne, stillede Hal Koch sig kritisk til, men grundlæggende solidarisk med de skiftende regeringers politik med det argument, at der var tale om en løsning, der havde den bredest mulige folkelige opbakning, hvilket valget i marts 1943 bekræftede. Løgstrup var anderledes radikal. Han krævede opslutning om absolutte værdier: "Men det jeg vilde sige dig, det er, at kommer du ved din Lydighed mod den Absoluthed, der er over vort Liv, i Kampen mellem Gud og Satan, saa er du ikke ansvarlig i noget Stykke for den Kamps Følger - det Ansvar kan du slet ikke bære, det er et umenneskeligt Ansvar, og det er gudløst at ville paatage sig det $i$ et Forsøg paa at beregne det." (6/12-41)

Der er en stærk klangbund af Tidehverv i Løgstrups argumentation: Mennesket må ikke prætendere at tage Guds ansvar 
på sig. Sammenhængen var, at et brud med tyskerne ville medføre jødelovgivning. Og hvis var så ansvaret for jødernes deportation? Hal Koch fastholdt samarbejdslinjen, blandt andet fordi det skånede danske liv. Han kunne godt misunde nordmændene de klare linjer, men "bliv mig saa fra Livet med det Sludder om det absolute og dansk Politik." (14/12-41). Man kan også tage denne forskel i deres måde at tænke på som et udtryk for den vej, de hver især tog inden for teologien. Hal Koch havde som historiker sans for det relative, mens Løgstrup som dogmatiker var vant til at tænke i absolutter.

Initiativet i korrespondancen var Løgstrups. Hans breve var ofte lange, sprudlende traktater, mens Hal Kochs svar kunne være meget korte, endda lidt korte for hovedet. Ikke alene havde Løgstrup antagelig mere tid til at korrespondere, han sad også langt fra København og de store beslutninger og kunne tillade sig den luksus at hævde absolutte principper. Hal Koch sad på sin side som formand for Dansk Ungdomssamvirke meget tæt på de vigtigste politikere og kunne se ræsonnementet i deres handlinger, "bedærvede af den Vigtighedens Atmosfære, man kommer ind i, naar man lever sit Liv i 'vigtige Forhandlinger"', som Løgstrup skrev. Løgstrup mente, at kompro- miset og den nationale enighed var blåøjet og naiv. Selv om man ved et brud med tyskerne kun fik halvdelen af danskerne med sig, drejede det sig om den gode halvdel med instinkterne og energien i behold (6/12-41). Grunden til Hal Kochs demokratisyn, der netop bestod i en respekt for alles synspunkter og ikke kun den ene halvdels, blev lagt med denne korrespondance, hvorimod Løgstrup udviklede synspunkter, der sagtens kunne forveksles med f.eks. Kaj Munks. På den anden side var det netop Løgstrup, der advarede Hal Koch om (10/1140), at Dansk Ungdomssamvirkes nationale appeller ikke adskilte sig væsentligt fra nazisternes. Som Tidehvervsmand var Løgstrup allergisk over for patos. Det forhindrede ham dog ikke i selv blot et år senere at øse af den nationalkonservative retorik, mens $\mathrm{Hal}$ Koch i samme periode forlod en opviglet og stærkt national grundtvigsk tone til fordel for en politisk pragmatisme og en markant antinazisme, der medførte et af besættelsestidens første bombeanslag mod hans hus.

Nissens eget oprindelige forord er heldigvis taget med i denne udgave. Det er forbilledligt enkelt, kortfattet, præcist og klogt. Ove Korsgaards nyforfattede efterord giver et fint supplement til Nissens tekst, idet Korsgaard meget præcist 
karakteriserer brevvekslingen og ikke mindst de faser, den gennemgår. Noterne til udgivelsen er sparsomme. Især de første 10 breve kunne godt fortjene væsentlig mere kontekst, nogle relevante kommentarer og litteraturhenvisninger samt nogle flere biografiske oplysninger. Her kan suppleres med et par stykker: I brevene 26/1-34 og 19/5-35 omtaler Hal Koch en 'Oskar' og begge gange som et svin. Der er tale om J. Oskar Andersen, hvis professorat Hal Koch endte med at overtage. De blev aldrig gode venner. I brevene af 7/8 og 18/10-35 refererer $\mathrm{Hal} \mathrm{Koch} \mathrm{til} \mathrm{en}$ 'Jonas', som var hans gamle klassekammerat fra Metropolitanskolen, Johannes Munck, senere professor i nytestamentlig eksegese i Aarhus og rektor for Aarhus Universitet. En tredje klassekammerat var i øvrigt Franz Blatt, professor i klassisk filologi og også rektor sammesteds. Derudover står Knud Bang anført som præst i Mørke 1936-80. Han var præst og siden provst 1937-72 og døde i 1982.

RIKKE LOUISE PETERS

\section{Til en misbrugets fænomenologi}

Thomas De Quincey: En engelsk opiumbrugers bekendelser, Suspiria de Pro- fundis, Den engelske postvogn, oversat af Hans-Jorgen Birkmose, Klim, 2010, 265 sider, 299,- ker.

Thomas De Quinceys (1785-1859) En engelsk opiumbrugers bekendelser var en skandalesucces fra første færd, da den udkom i England i 1821. Bekendelserne udkom anonymt, men blev straks omgæret af en blanding af nyfigen interesse og borgerlig forargelse, der som bekendt har det med af følges ad.

De Quinceys tre tekster En engelsk opiumbrugers bekendelser, Suspiria de Profundis og Den engelske postvogn, de såkaldte opiumtekster, er netop nyoversat og genudgivet samlet på Forlaget Klim med et efterskrift af Hans-Jørgen Birkmose, der fint beskriver, hvordan offentlighedens forargelse fulgte den klassiske opskrift med at afvise værket under henvisning til, at det kunne lokke ungdommen i fordærv og efter sigende havde været årsag til flere dødsfald. Men som Birkmose også beretter, var der intet glamourøst eller efterstræbelsesværdigt ved De Quinceys liv som småsyg opiumdranker og konstant fattig freelanceskribent.

Alligevel er opiumteksterne lidt af en litterær bedrift og intet mindre end et hovedværk $\mathrm{i}$ bekendelses- og misbrugsgenren. Opiumteksterne giver på den ene side mindelser om et værk som 